\title{
Physical properties and their relationship to sedimentary processes and texture in sediments from mud volcanoes in the Anaximander Mountains (Eastern Mediterranean)
}

\author{
DAVID CASAS ${ }^{1}$, GEMMA ERCILLA ${ }^{1}$, VASILIS LYKOUSIS ${ }^{2}$, CHRYSSANTHI IOAKIM $^{3}$ \\ and CONSTANTINE PERISSORATIS ${ }^{3}$ \\ ' Institut de Ciències del Mar-CSIC. Passeig Marítim de la Barceloneta. 37-49. Barcelona. Spain. \\ ${ }^{2}$ National Centre for Marine Research- NCMR. Ag. Kosmas, Elliniko, 16604 Athens. Greece. \\ ${ }^{3}$ Institute of Geology \& Mineral Exploration.70 Messoghion St. Athens 11527, Greece.
}

\begin{abstract}
SUMMARY: This research focuses on the mud volcanoes Amsterdam, Kazan and Kula located in the Anaximander Mountains (SW Turkey continental margin), which are characterized by the presence of sediments containing gas and gas hydrate. These mud volcanoes were sampled by recovering four gravity cores. For sediment located right on top (crater or active part of the summit) of the mud volcanoes, the physical properties are controlled by lithology and mud volcanic processes rather than the degree of compaction. This could suggest the possibility of current mud volcanic activity. In contrast, the sediment located in the external flank of Kula mud volcano displays physical properties mostly related to consolidation effects and to the type of sediment at a detailed scale, as occurs typically in deep-sea fine grained sediments. This suggests a restricted influence of mud volcanic processes.
\end{abstract}

Keywords: Anaximander, mud volcano, physical properties, sediment texture, index property, gas.

RESUMEN: RELACIONES ENTRE LAS PROPIEDADES FÍSICAS, PROCESOS SEDIMENTARIOS Y TEXTURA EN SEDIMENTOS DE LOS VOLCANES DE FANGO EN LAS MONTAÑAS ANAXIMANDER (MEDITERRÁNEO ORIENTAL). - Este trabajo se centra en el estudio de sedimentos procedentes de los volcanes de fango Amsterdam, Kazan y Kula localizados en las montañas submarinas Anaximander (SO del margen continental de Turquía), caracterizados por la presencia de sedimentos que contienen gas e hidratos de gas. Estos volcanes de fango se muestrearon con cuatro testigos de gravedad. En los sedimentos localizados en los cráteres (o en las cimas activas) de los volcanes de fango, las propiedades físicas están básicamente controladas por la litología y procesos volcánicos. Esto sugiere un actividad volcánica reciente. Por el contrario, el sedimento localizado en el flanco externo de Kula presenta unas propiedades físicas básicamente relacionadas con el efecto de consolidación y, a escala de detalle, con el tipo de sedimento como ocurre en general en sedimentos marinos profundos. Esto sugiere una influencia restringida de los procesos volcánicos.

Palabras clave: Anaximander, volcanes de fango, propiedades físicas, textura, propiedades índice, gas.

\section{INTRODUCTION}

This research project focuses on the mud volcanoes Amsterdam, Kazan and Kula (Fig. 1), which are located in the Anaximander Mountains (SW Turkey continental margin). These volcanoes are characterized by the presence of gas and gas hydrates (Woodside et al., 1998; Lykousis et al., 2003; Lykousis et al., 2004; Werne et al., 2004). The term mud volcanism refers to a range of sedimentary processes that result in the extrusion of argillaceous material, and occurs both on land and on the 
seafloor (Milkov, 2000). The presence of mud volcanoes is associated with the presence of high seafloor methane fluxes as well as with the accompanying cold vents, seeps (Charlou et al., 2003), carbonate crusts (Aloïsi et al., 2002) and gas hydrates under certain conditions. Therefore, they play an important role in scientific issues such as sediment stability, climate and environmental studies, and the interplay between microbial life and fluid seepage (Olu et al., 2004).

Physical properties of marine sediments are important variables in order to understand geological events in marine environments and they play an important role in determining the nature of fluid and gas migration, which in turn affects the nature of microbial communities and gas hydrate formation. Several studies have been conducted to examine the relationship between physical and textural parameters of marine sediments (Orsi and Dunn, 1991; Weber et al., 1997; Kim et al., 2001; Casas et al., 2004). The physical properties of sediment depend to a large extent on lithology, grain size and the proportion of the different components of the sediment (e.g. clay, quartz, biogenic carbonate and silica) (Hamilton et al., 1982; Nobes et al., 1991). The wetbulk density, for example, is related to porosity and grain density, and is partially controlled by grain size (Johnson and Olhoeft, 1984). The acoustic

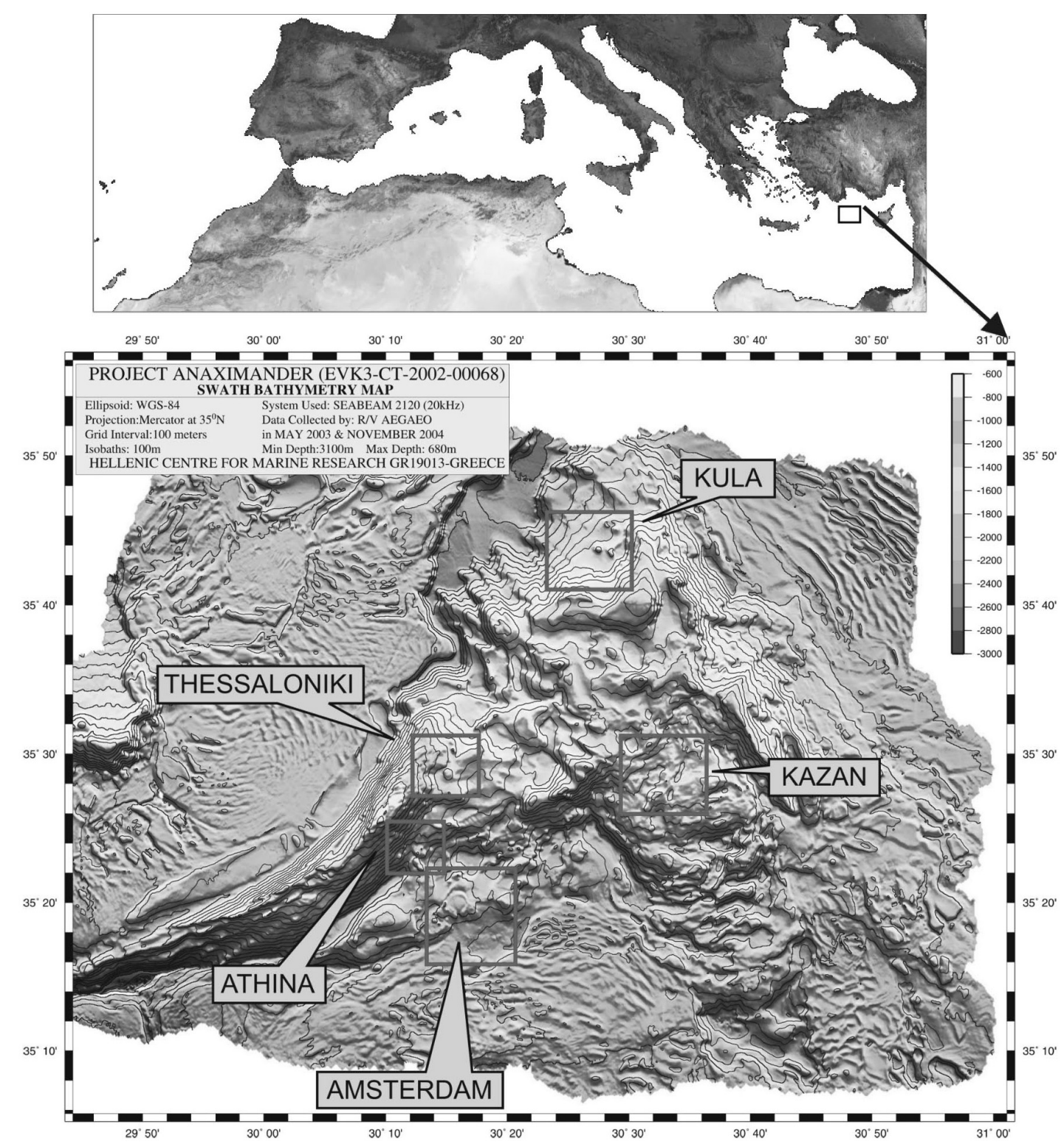

FIG. 1. - Map showing the location of the Anaximander Mts. and Amsterdam, Kula and Kazan mud volcanoes. 


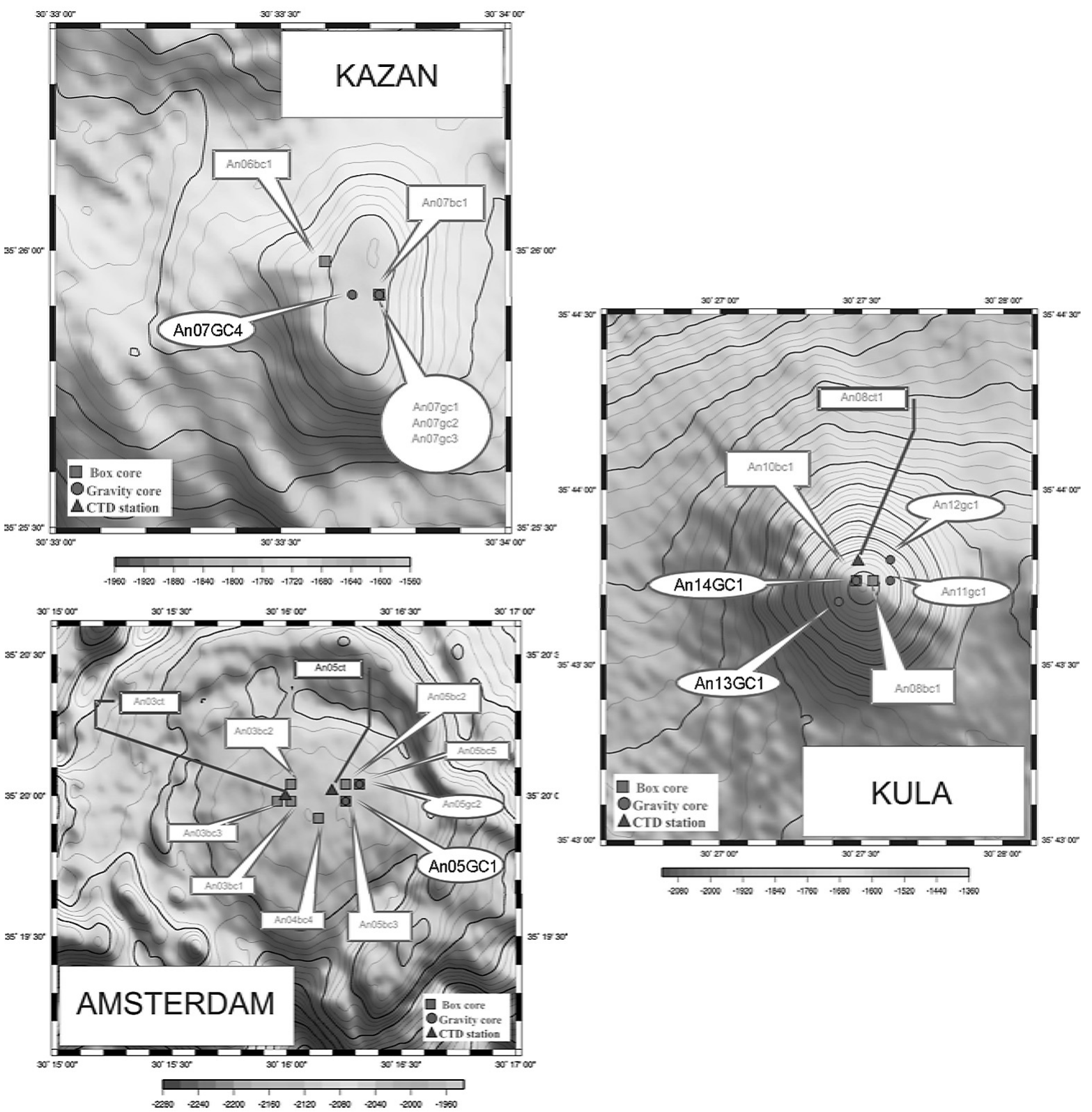

FIG. 2. - Amsterdam, Kula and Kazan mud volcanoes, showing the location of all cores recovered from each volcano. The locations of the four cores under study have been highlighted.

velocity is controlled by porosity and carbonate and clay content (Hamilton et al., 1982; Mienert, 1984; Nobes et al., 1986). Physical properties are also influenced by diagenetic effects, especially by the decrease in porosity with increasing compaction, but also by cementation and carbonate dissolution (Nobes et al., 1992).

This research project makes a detailed analysis of the relationships between the physical properties and the sedimentological characteristics of the sediments containing gas hydrate recovered in mud volcanoes from the Anaximander Mountains (Fig. 1). The aim of this work is to define the type of sedi- ments associated with mud volcanoes in order to establish the processes which formed them and to determine the effects of sedimentological changes on the physical properties of these sediments.

\section{GEOLOGICAL SETTING}

The Anaximander Mountains are located in one of the most rapidly subsiding sections of the Mediterranean (Fleming, 1972), where interaction between the Anatolian and African Plates takes place. These mountains are currently undergoing a 
TABLE 1. - Location, depth of analyzed cores and their location in the mud volcanoes.

\begin{tabular}{|c|c|c|c|c|c|}
\hline Core & Core length & Depth & $\varphi$ & $\lambda$ & Mud volcano \\
\hline An05GC1 & $131 \mathrm{~cm}$ & $2030 \mathrm{~m}$ & $35^{\circ} 20^{\prime} 002$ & $30^{\circ} 16^{\prime} 263$ & Amsterdam \\
\hline An07GC4 & $148 \mathrm{~cm}$ & $1700 \mathrm{~m}$ & $35^{\circ} 25^{\prime}, 908$ & $30^{\circ} 33^{\prime} 689$ & Kazan \\
\hline An13GC1 & $81 \mathrm{~cm}$ & $1636 \mathrm{~m}$ & $35^{\circ} 43^{\prime} 701$ & $30^{\circ} 27^{\prime}, 400$ & Kula \\
\hline An14GC1 & $85.5 \mathrm{~cm}$ & $1636 \mathrm{~m}$ & $35^{\circ} 43^{\prime} 716$ & $30^{\circ} 27^{\prime} 502$ & Kula \\
\hline
\end{tabular}

neotectonic deformation phase characterized by strike slip faulting with subsidiary normal faulting and some minor thrusts within a zone of accommodation between the above-mentioned plates (McClusky et al., 2002; Zitter et al., 2003; Ten Veen at el., 2004). At least seven mud volcanoes (such as Amsterdam, Kula and Kazan) have been observed in the area, and more than 25 dome-like mud volcanoes have been identified (Woodside et al., 1997, 1998; Lykousis et al., 2004). The three mud volcanoes under study (Fig. 2) appear respectively as elliptical (about $100 \mathrm{~m}$ high and $3 \mathrm{~km}$ width), hemispherical (about $80 \mathrm{~m}$ high and $1 \mathrm{~km}$ width) and irregular (about $50 \mathrm{~m}$ high and $800 \mathrm{~m}$ width) reliefs (Zitter et al., 2005). Their origin is associated with the structural situation characterized by a compression zone that favours the expulsion of overpressured fluids at the surface. There are several acoustic evidences in the area that suggest the presence of gas in the sediments, such as acoustic turbidity, acoustic wipe-outs and pockmarks. Likewise, sediment containing interstitial free gas, gas hydrate, and carbonate crusts have been recovered from these volcanoes (Woodside et al., 1988; Lykousis et al., 2003).

\section{METHODOLOGY}

The present study was carried out on four gravity cores (An05GC1, An07GC4, An14GC1 and An13GC1, Table 1) recovered from the Amsterdam, Kazan and Kula mud volcanoes (Fig. 2) during the first cruise of the European project Anaximander, onboard the R/V Aegaeo of the Hellenic Centre for Marine Research. The laboratory methodology comprised measurements made in order to determine the textural and compositional characteristics and the physical and index properties of the types of sediments. Textural and compositional analyses were done and index property measurements were made of discrete samples, whereas the physical properties comprise continuous measurements.
The textural analysis gives information about the grain-size of sediments which is of great interest for determining the transport and deposition mechanism. Textural analysis was carried out on selected samples by hand sieving for the $>2000 \mu$ fraction, settling tube (Giró and Maldonado, 1987) for the 2000 to $50 \mu$ fraction, and Sedigraph 5100D (Stein, 1985) for the $<50 \mu$ fraction.

Continuous, non-destructive high-resolution measurements of whole-round core sections were obtained with the Multi-Sensor Core Logger (MSCL). The parameters measured include wetbulk density (by Gamma Ray Attenuation, GRAPE), magnetic susceptibility (MS) and P-wave velocity (Weber, 1997). The typical sampling rate was about one measurement every $1 \mathrm{~cm}$.

Compositional analysis is important in order to determine the nature and origin of sediments. This analysis comprised determining the sand fraction composition and calcium carbonate content. The composition of the sand fraction was determined by visual identification and by counting 350 grains per sample using a binocular microscope. Calcium carbonate content in the samples was determined using the gasimetric method with a modified Bernard calcimeter, according to the method described by Vatan (1967).

Discrete measurements of physical properties include the index properties water content, grain density, porosity and undrained shear strength. The index properties were determined by gravimetric techniques using the salt-corrected weights and volumes as outlined by Hamilton (1970), assuming an interstitial pore-water salinity of $35 \%$. Soft sediments were sampled and placed in precalibrated aluminium beakers. Mean sample weights were determined using an electronic balance. Sample volumes were determined using a helium-displacement AccuPyc 1330 Pycnometer. The samples were ovendried for $24 \mathrm{~h}$ at about $105^{\circ} \mathrm{C}$, and the dry weight and volume were again measured. Porosity was calculated combining the index properties of discrete samples (grain density) and Gamma-ray density 


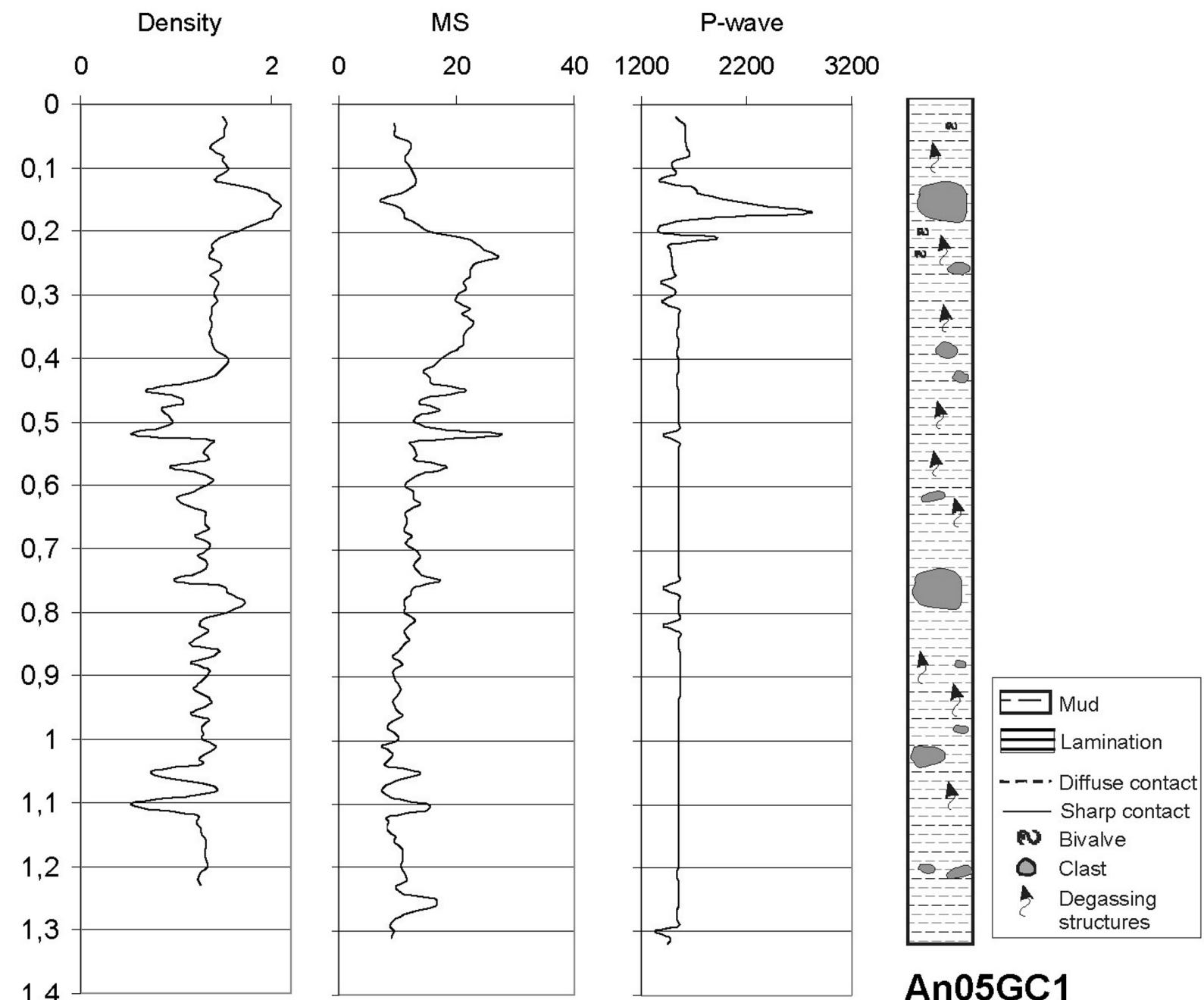

FIG. 3. - Core logs illustrating the vertical distribution of bulk density values $\left(\mathrm{g} / \mathrm{cm}^{3}\right)$, magnetic susceptibility $\left(10^{-6} \mathrm{SI}\right)$, P-wave velocity $(\mathrm{m} / \mathrm{s})$ and sediment for the core An05GC1. Vertical scale in metres.

(MSCL). Porosity $(\phi)$ and density $\left(\rho_{\mathrm{b}}\right)$ are related by the following equation using grain density $\left(\rho_{g}\right)$, which was on average $2.7 \mathrm{~g} / \mathrm{cm}^{3}$, and pore-water density $\left(\rho_{\mathrm{w}}\right)$, which was assumed to be $1.025 \mathrm{~g} / \mathrm{cm}^{3}$

$$
\phi=\left(\rho_{\mathrm{g}}-\rho_{\mathrm{b}}\right) /\left(\rho_{\mathrm{g}}-\rho_{\mathrm{w}}\right)
$$

The undrained shear strength $\left(\mathrm{S}_{\mathrm{u}}\right)$ of soft cohesive sediments was measured with a WyckehamFarrance motorized vane shear device.

\section{RESULTS}

\section{Sedimentology}

The four cores studied (Figs. 3, 4, 5, 6.) are located in different sedimentary environments. Cores
An05GC1, An07GC4 and An14GC1 are sited inside the crater of the Amsterdam, and in the active summit of Kazan and Kula mud volcanoes respectively. Core An13GC1 is sited at the outflowing masses that form the external flank of the Kula volcano. Table 1 presents the details of the core locations. The stratigraphy of cores An05GC1, An07GC4 and An14GC1 comprises mud breccias (Figs. 3, 4, 6.) characterized by a muddy, matrix-supported and very poorly sorted sediment with angular to subangular clasts of mudstone of different compositions and grain sizes $(0.5$ to $2.5 \mathrm{~cm})$. General porous gasrelease structures are the predominant sedimentary structure. This is because disseminated gas hydrate was recovered in this type of sediment, but it dissociated during the sampling operation or minutes later onboard, when its stable P-T conditions changed (Kvenvolden, 1993; Pellenbarg and Max, 
Density

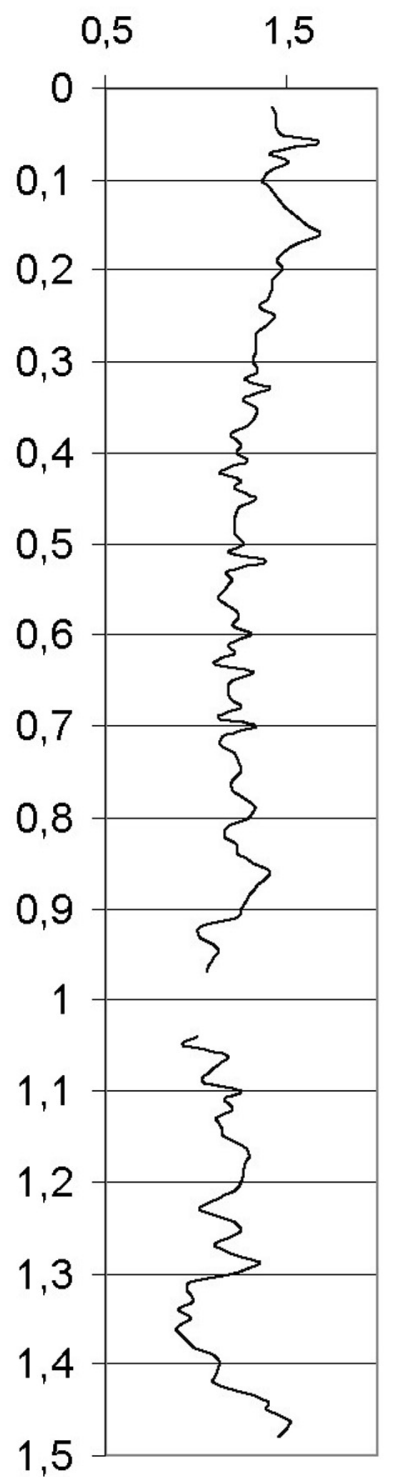

MS

10

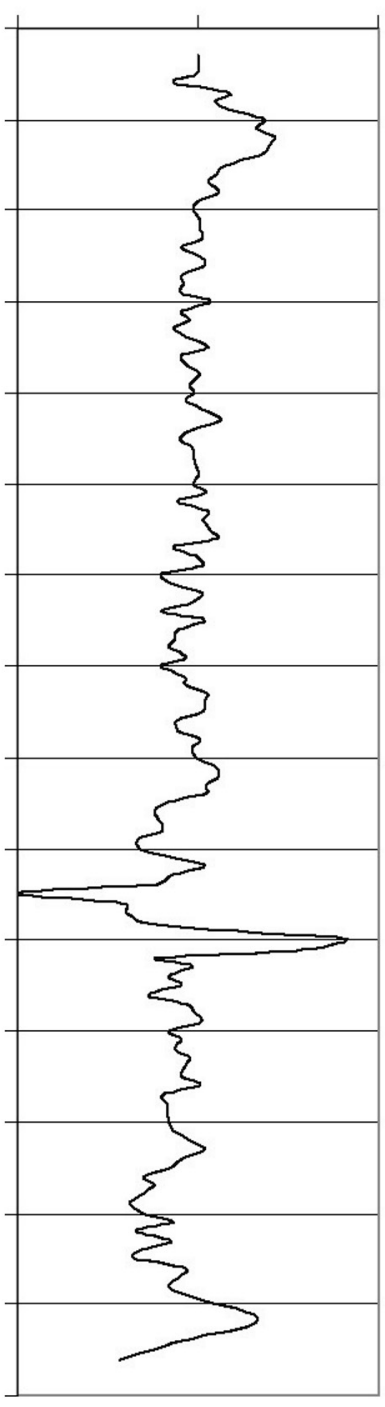

P-wave

$201200 \quad 1700$

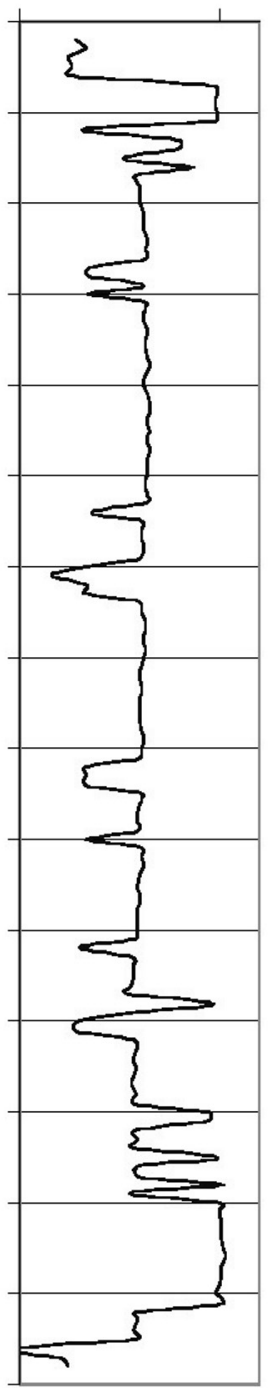

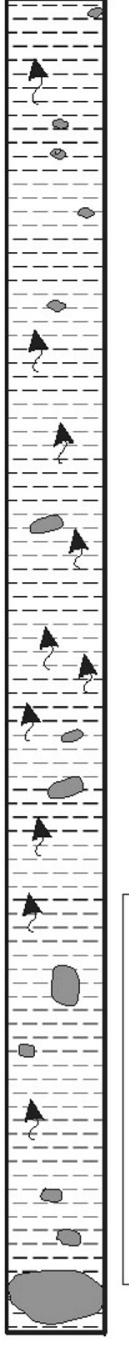

$E-7$ Mud

E Lamination

- - - Diffuse contact

- Sharp contact

o Bivalve

- Clast

Degassing structures

\section{An07GC4}

FIG. 4. - Core logs illustrating the vertical distribution of bulk density values $\left(\mathrm{g} / \mathrm{cm}^{3}\right)$, magnetic susceptibility $\left(10^{-6} \mathrm{SI}\right), \mathrm{P}$-wave velocity $(\mathrm{m} / \mathrm{s})$ and sediment for the core An07GC4. Vertical scale in metres.

2000). Shells of bivalves (Lucinoma kazani) were observed in the top of core An05GC1. This mollusc is typically associated with cold seep venting in the eastern Mediterranean (Salas and Woodside, 2002) and described in other mud volcanoes in the area as "Athina" mud volcano (Lykousis et al., 2006).

In contrast, core An013GC1 (Fig. 5) is defined by a mud breccia which towards the top changes to hemipelagic mud ( $50 \mathrm{~cm}$ thick); the contact between the two types of sediment is sharp and the top of the mud breccia (first $12 \mathrm{~cm}$ ) is oxidized. Within the hemipelagic sediments, an organic-rich (black) bed between 15 to $33 \mathrm{cmbsf}$ (centimetres below sea floor) was identified as the early Holocene sapropel S1 (Rijk et al., 1999).

The results of the grain-size analysis on the muddy matrix of the mud breccia and hemipelagic mud show low variability of grain-size distributions between cores. According to the percentages of the three main size-fractions, most of the analyzed samples are classified as silty clays (55-67\% of clay) and clayey silts (46\% silt), with only small amounts of sands $(7 \%)$ and gravels $(<10 \%)$. Mean grain sizes mainly vary between 5 and 8.7 phi.

The sand fraction of the mud breccia is basically characterized by terrigenous components (Fig. 7A.). 
Density
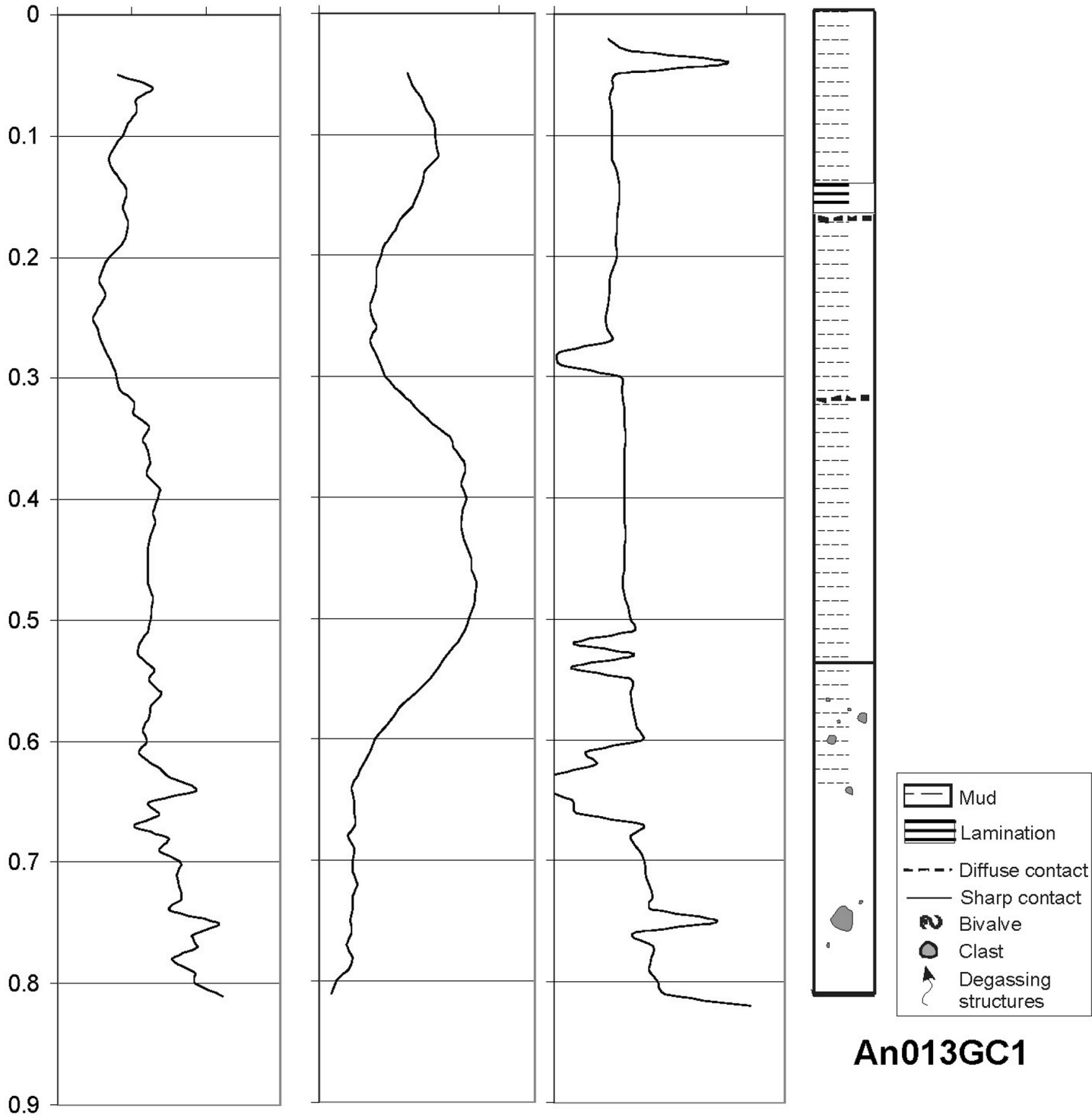

An013GC1

FIG. 5. - Core logs illustrating the vertical distribution of bulk density values $\left(\mathrm{g} / \mathrm{cm}^{3}\right)$, magnetic susceptibility $\left(10^{-6} \mathrm{SI}\right)$, P-wave velocity $(\mathrm{m} / \mathrm{s})$ and sediment for the core An13GC1. Vertical scale in metres.

The average value of all the terrigenous components ranges between 89 and $99 \%$. They are essentially quartz, light minerals, rock fragments and a maximum of $7 \%$ oxidized pyrite (Fig. 7B). In core An05GC1 a greater relative weight of rock fragments can be observed, with a maximum of $32 \%$. The sand fraction of hemipelagites shows the highest percentage of biogenic components, with values close to $100 \%$. These components are basically planktonic foraminifera (Fig. 7C).

Calcium carbonate contents of mud breccias have average values of $<29 \%$, showing small differences between the cores. In the hemipelagic muds the average carbonate value is $34 \%$, with a maximum value of $49 \%$ (Fig. 8 ).

\section{Physical properties}

\section{Bulk Density}

Measured density values range between 1.2 and $2.1 \mathrm{~g} / \mathrm{cm}^{3}$, but the values show a large scattering which may partially correspond to fine-scale lithologic variations. In spite of the variable profile marked by many spikes, the downcore trend of the average density for cores An05GC1, An07GC4 and An14GC1 

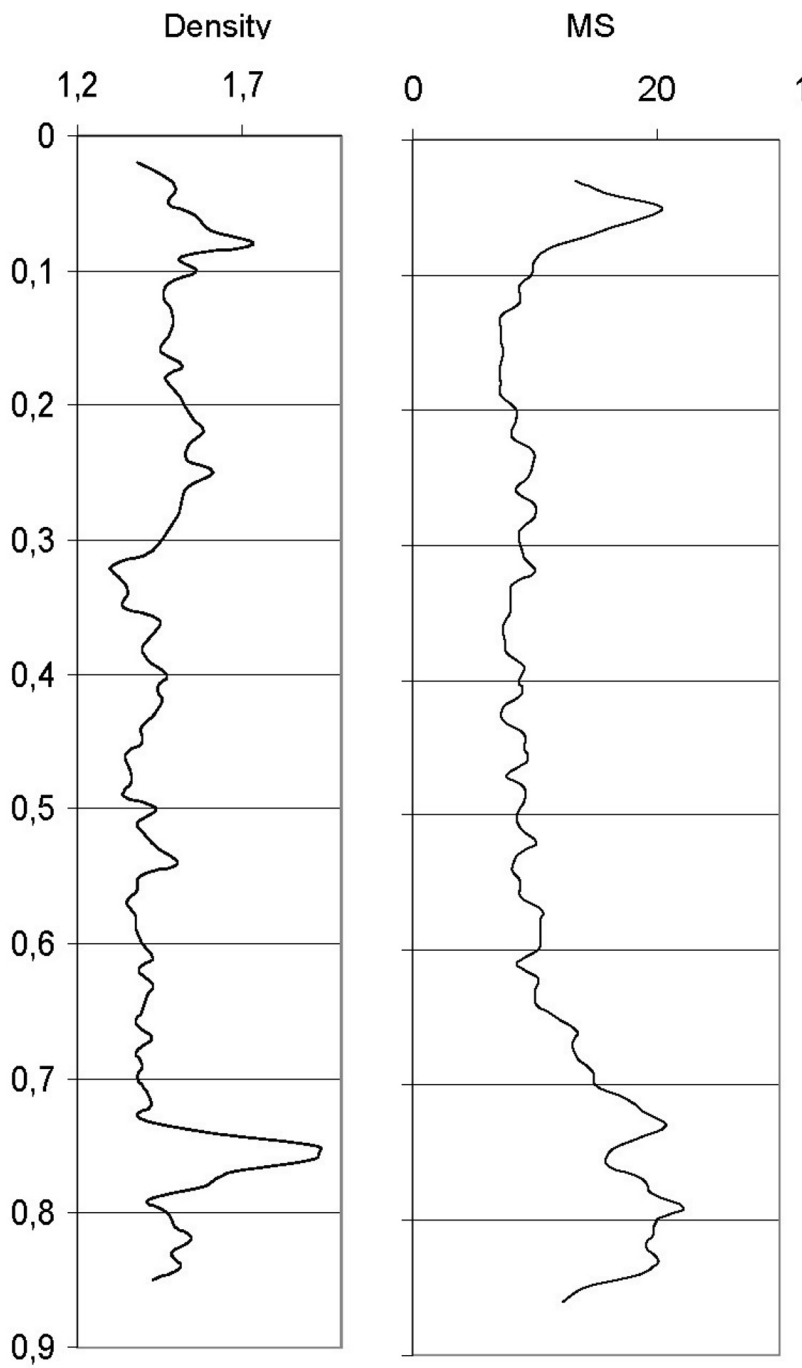
P-wave

$1300 \quad 1800$
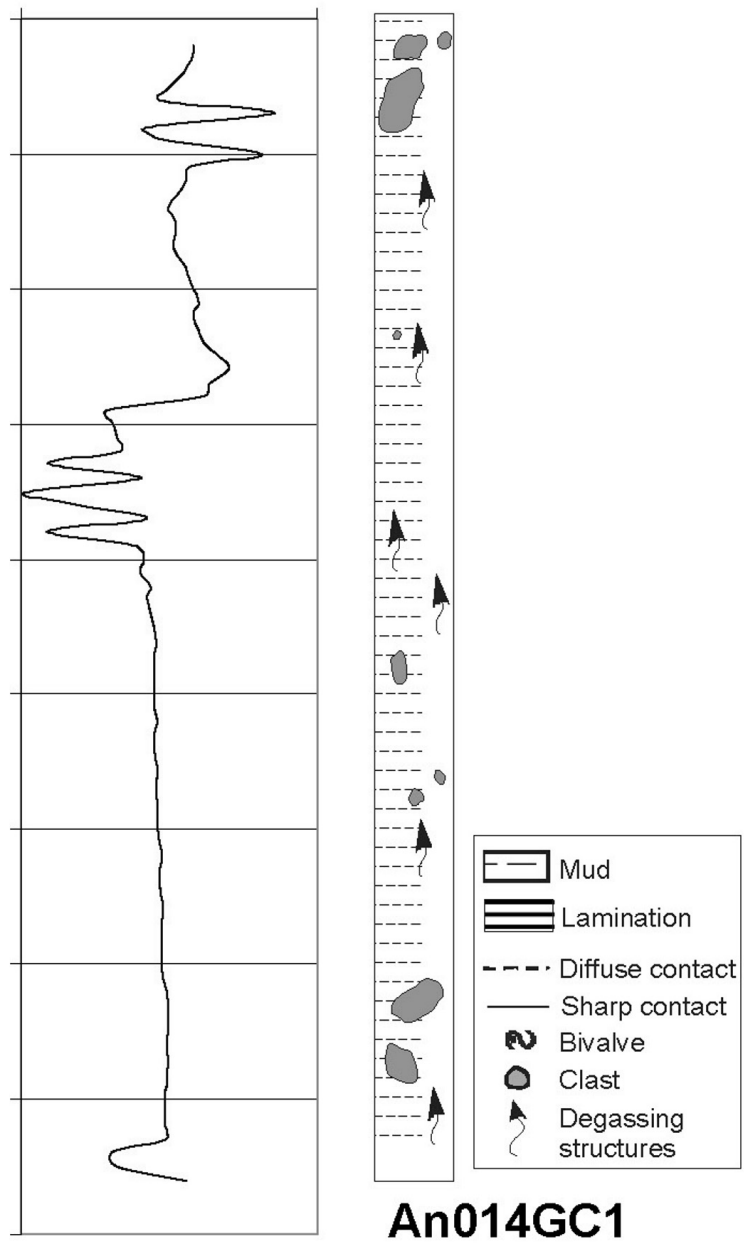

FIG. 6. - Core logs illustrating the vertical distribution of bulk density values $\left(\mathrm{g} / \mathrm{cm}^{3}\right)$, magnetic susceptibility $\left(10^{-6} \mathrm{SI}\right), \mathrm{P}-\mathrm{wave}$ velocity $(\mathrm{m} / \mathrm{s})$ and sediment for the core An14GC1. Vertical scale in metres.

is quite similar. Therefore, density values vary between $1.46 \mathrm{~g} / \mathrm{cm}^{3}$ in $\mathrm{An} 05 \mathrm{GC} 1,1.49 \mathrm{~g} / \mathrm{cm}^{3}$ in An07GC4 and An14GC1 near their tops, and 1.27 $\mathrm{g} / \mathrm{cm}^{3}$ in An05GC1, $1.45 \mathrm{~g} / \mathrm{cm}^{3}$ in An07GC4 and 1.48 $\mathrm{g} / \mathrm{cm}^{3}$ in An14GC1 near their bottoms (Figs. 3, 4, 6). Only the core An13GC1 showed a general trend to increase downcore (Fig. 5). In this core, the density value was $1.4 \mathrm{~g} / \mathrm{cm}^{3}$ near the top and increased down core to $1.58 \mathrm{~g} / \mathrm{cm}^{3}$ from 75 and $80 \mathrm{cmbsf}$.

The detailed study of the profiles illustrates the correspondence between density variations and sediment types. The above-mentioned general trend is locally interrupted with sharp increases which usually correspond to the coarser-grained sediment or the presence of some large clasts (rock fragments); these intervals show the greatest relative differences observed for each core and are where maximum density values $\left(1.93-2.1 \mathrm{~g} / \mathrm{cm}^{3}\right)$ were recorded. Some of these intervals are easily recognizable: e.g. the intervals 13-19 cm in An05GC1 (Fig. 3), 143$149 \mathrm{~cm}$ in An07GC4 (Fig. 4), 73-79 cm in An14GC1 (Fig. 6) and 62-64 cm in An13GC1 (Fig. 5).

\section{Magnetic Susceptibility}

Magnetic susceptibility (MS) is a measure of the concentration of the magnetizable components within the sediment. Variations in the MS values of deepsea sediments may reflect changes in lithology (the proportion of biogenic components (carbonate and silica) to lithogenic components (clay and labile minerals), which is essentially one of the bases for the lithological classification of deep-sea sediments (Robinson, 1990; Sager and Hall, 1990). 

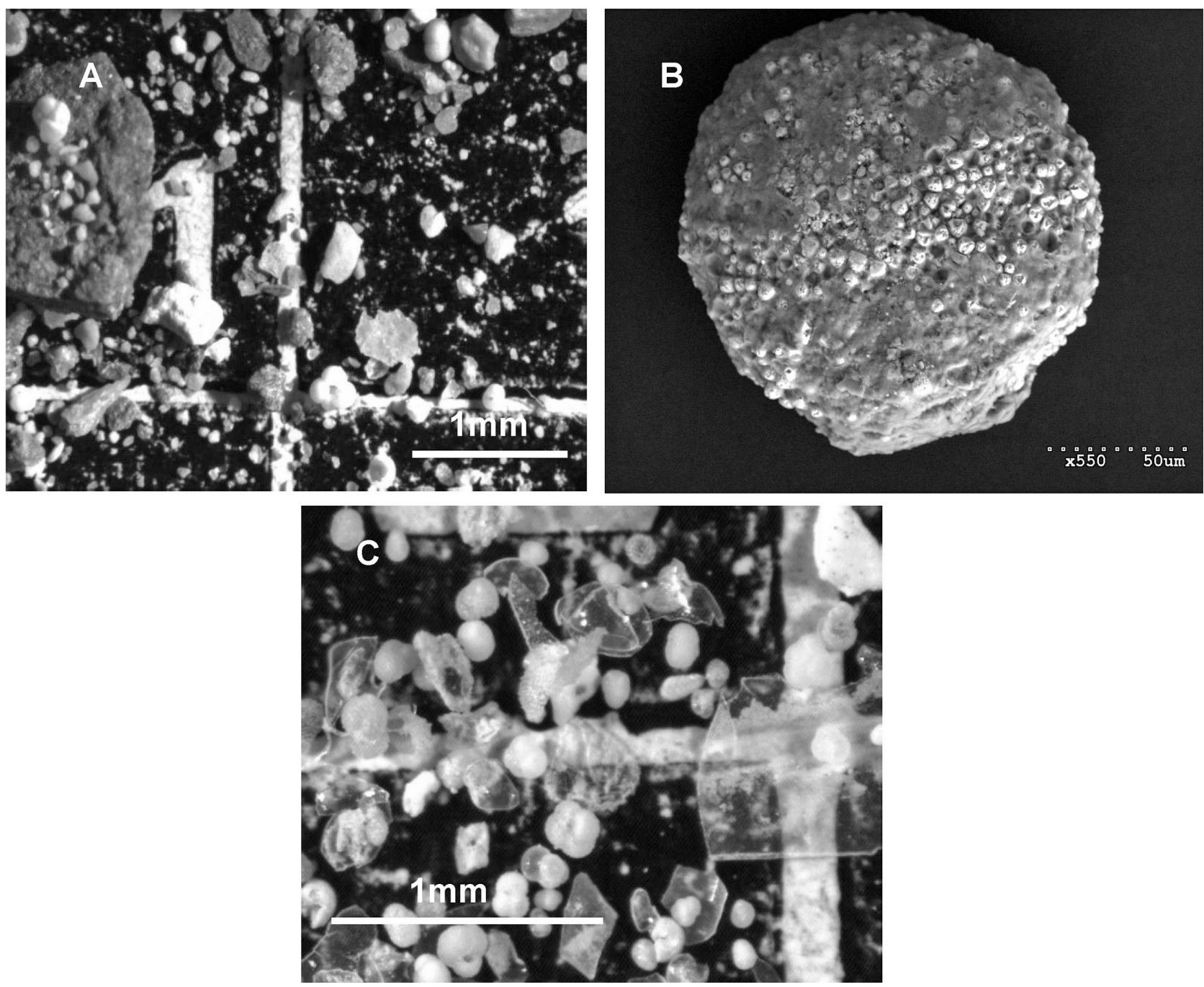

FIG. 7. - (A) Microscope picture of the mud breccia showing the terrigenous components of the sand fraction (B) Electron microscope image showing the alterated crystals of pyrite found as a component of the mud breccia and (C) Microscope picture of hemipelagic sediment showing the biogenic components of sand fraction.

MS measurements show average values of about $13 \cdot 10^{-6}$ SI units in An05GC1, 9.10-6 SI units in An07GC4, $11 \cdot 10^{-6}$ SI units in An14GC1 and $24 \cdot 10^{-6}$ SI units in An13GC1. There are some differences regarding the general trend of the cores (Figs. 3, 4, 5, 6). Cores An05GC1, An07GC4 and An14GC1 have a comparable "behaviour" showing low variability with depth but the average trend is punctuated by spikes with values as great as $27 \cdot 10^{-6}$ SI units $(52 \mathrm{~cm}$ in An05GC1), $18 \cdot 10^{-6}$ SI units (100 cm in An07GC4) and $22 \cdot 10^{-6}$ SI units $(79 \mathrm{~cm}$ in An014GC1). The spikes observed in these cores occur throughout the entire $\log$, but they are not uniformly distributed. As occurs in the density log, all MS peaks seem to correlate with the presence of some rock fragments.

In contrast, core An13GC1 shows a different trend. It displays a general decrease downcore from
$24 \cdot 10^{-6}$ SI to $8 \cdot 10^{-6}$ SI. The detailed analysis of its vertical distribution allows three different intervals to be differentiated: i) 6 to $25 \mathrm{cmbsf}$, the MS values decrease downcore from 30 to $14 \cdot 10^{-6} \mathrm{SI}$; ii) 25 to 50 cmbsf, the MS values increase downcore from 15 to $41 \cdot 10^{-6} \mathrm{SI}$; and iii) $50 \mathrm{~cm}$ to bottom, the MS values decrease downcore from 40 to $3 \cdot 10^{-6}$ SI units (Fig. $5)$. The described intervals seem to coincide with the stratigraphy of the core, reflecting the different types of sediment as hemipelagites $v s$. organic-rich hemipelagites $v s$. mud breccia.

\section{Acoustic velocity}

The analysis of the acoustic velocity is useful for geophysical modelling and interpretation, and it may provide diagnostic information about lithologic vari- 


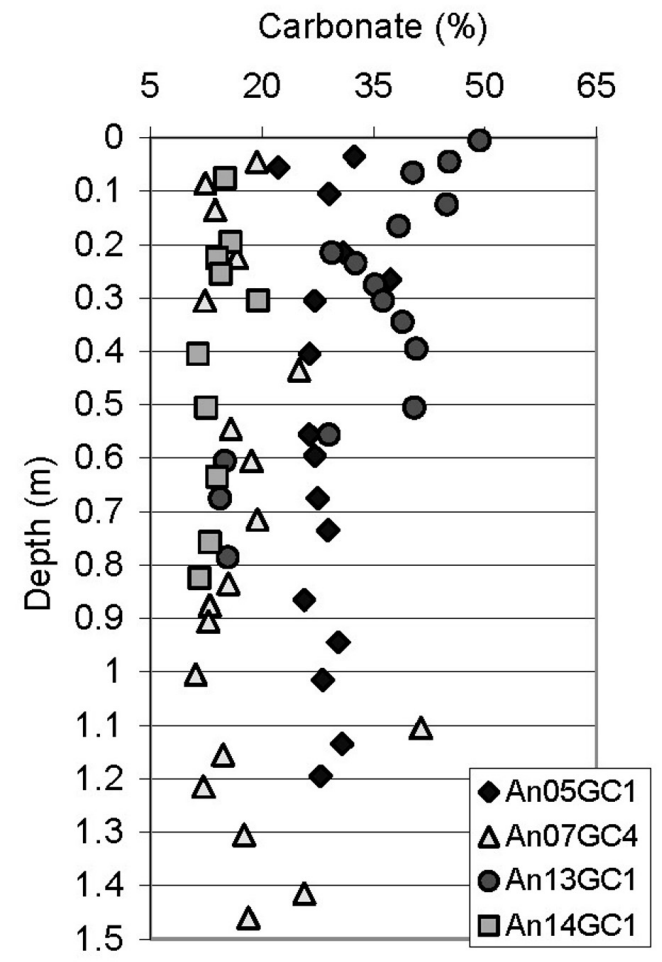

FIG. 8. - Downcore variation of carbonate content (\%) for cores An05GC1, An07GC4, An13GC1 and An14GC1.

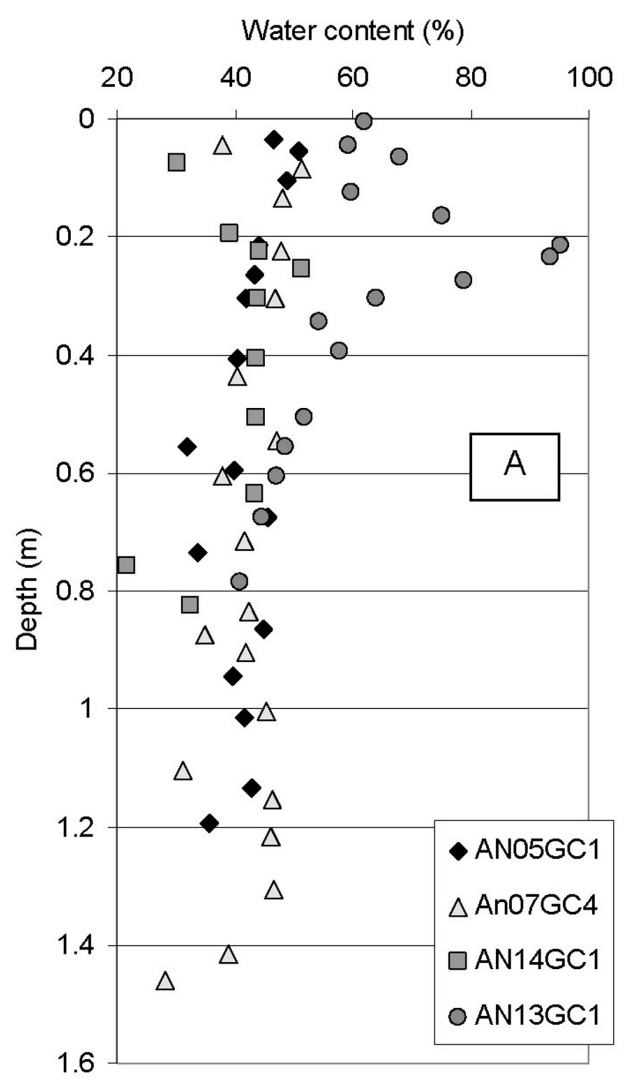

ations. Several studies have focused on the correlation of the acoustic velocity with porosity and lithology (Hamilton and Bachman, 1982; Nobes et al., 1986; Mienert et al., 1988; Fulthorpte et al., 1989), especially the clay and carbonate content (Hamilton et al., 1982; Mienert, 1984; Nobes et al., 1991).

Measured P-wave velocity values are generally low. Average acoustic velocities in cores An05GC1, An07GC4, An13GC1 and An14GC1 are close to 1587 $\mathrm{m} / \mathrm{s}, 1493 \mathrm{~m} / \mathrm{s}, 1588 \mathrm{~m} / \mathrm{s}$ and $1577 \mathrm{~m} / \mathrm{s}$ respectively near the mudline (Figs. 3, 4, 5, 6). Only An13GC1 shows a smooth downcore increase with depth to values close to $1691 \mathrm{~m} / \mathrm{s}$ at $80 \mathrm{cmbsf}$ (Fig. 5). P-wave logs show a scattering probably caused by sediment disturbance or bad acoustic contact (for example, see the last $10 \mathrm{~cm}$ of core An07GC4, Fig. 4).

\section{Discrete measurements}

\section{Water content}

Water content (\% dry weight) decreases downcore although the rate of decrease is variable (Fig. $9 \mathrm{~A})$. The higher values of water content $(>50 \%)$

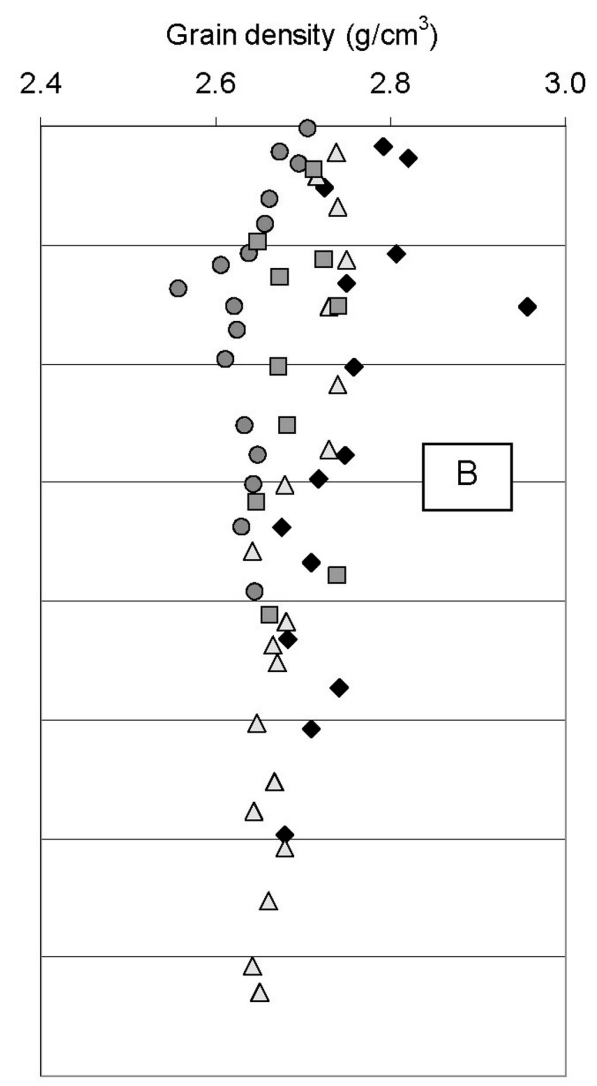

Fig. 9. - Downcore variation of (A) water content (\%) and (B) grain density $\left(\mathrm{g} / \mathrm{cm}^{3}\right)$ for cores An05GC1, An07GC4, An13GC1 and An14GC1. 
correspond in general to the most surficial samples, but the general trend of water content distribution in cores An05GC1, An07GC4 and An14GC1 (where the trend to decrease downcore is very low or null) contrasts with that of core An13GC1. The water content of the first group of cores decreases downward from $35-50 \%$ at the top to $21-35 \%$ at the bottom, while in core $\mathrm{An} 13 \mathrm{GC} 1$ it decreases downward from $62 \%$ at the top to $41 \%$ at the bottom. These top-bottom differences may result from consolidation processes although their distribution may also indicate differences in texture and/or different sediment-forming processes (Lee and Baraza, 1999; Nelson et al., 1999).

\section{Grain density}

Grain density depends on the minerals that form the sediment. It usually does not show a characteristic depth trend like water content and bulk density do. The grain density profile does not show marked trends downcore in the studied cores (Fig. 9B). In core An05GC1 the average grain density is 2.76 $\mathrm{g} / \mathrm{cm}^{3}$ but at $0.3 \mathrm{mbsf}$ it increases sharply to 2.96

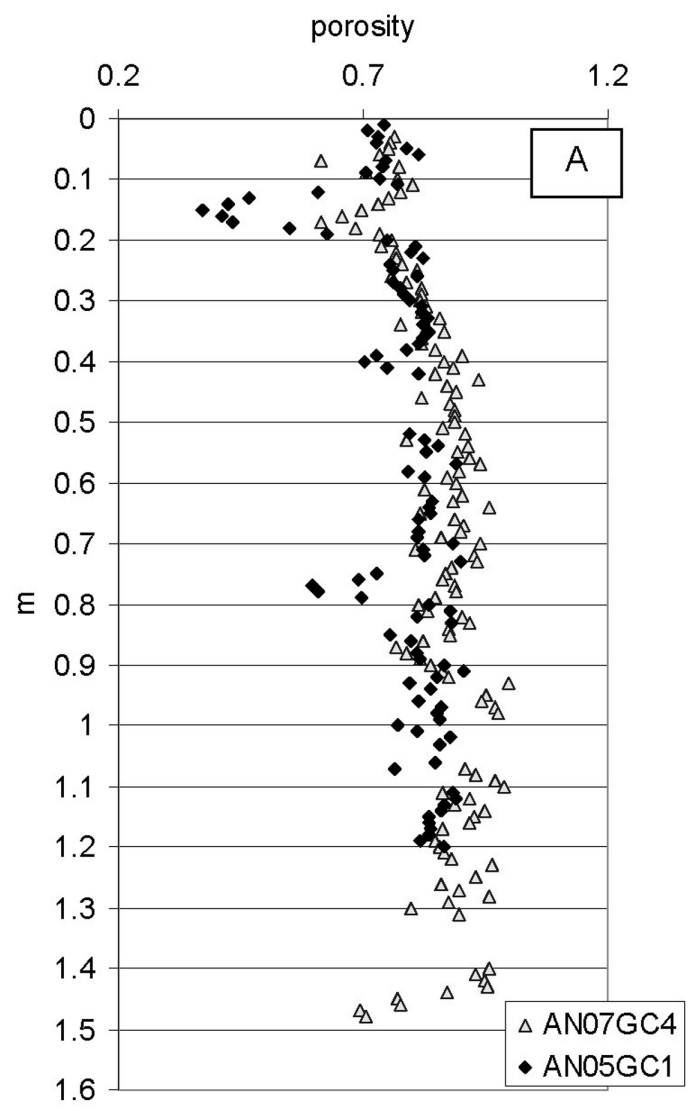

$\mathrm{g} / \mathrm{cm}^{3}$. In cores An07GC4 and An14GC1 the average grain density is 2.69 and $2.70 \mathrm{~g} / \mathrm{cm}^{3}$ respectively. The lowest grain density is recorded in core $\mathrm{An} 13 \mathrm{GC} 1$, which shows an average value of $2.64 \mathrm{~g} / \mathrm{cm}^{3}$ and a minimum value of $2.56 \mathrm{~g} / \mathrm{cm}^{3}$ at $0.27 \mathrm{mbsf}$.

\section{Porosity}

The porosity profile does not show a trend in core An07GC4, whose average value is $85 \%$ (Fig. 10). The profiles in cores An05GC1 and An14GC1 increase downcore and their average values are 77 and $73 \%$ respectively. The porosity only decreases downcore in core An13GC1 from $77 \%$ at the top to $66 \%$ at the bottom (Fig. 10). In this case an average value of $75 \%$ was calculated.

\section{Undrained shear strength}

The data obtained show a general but very low trend of increasing average strength downcore (except in core An07GC4) from nearly $2 \mathrm{kPa}$ at the top to $6 \mathrm{kPa}$ at the bottom (Fig. 11). The highest shear strength is recorded in core An13GC1, which

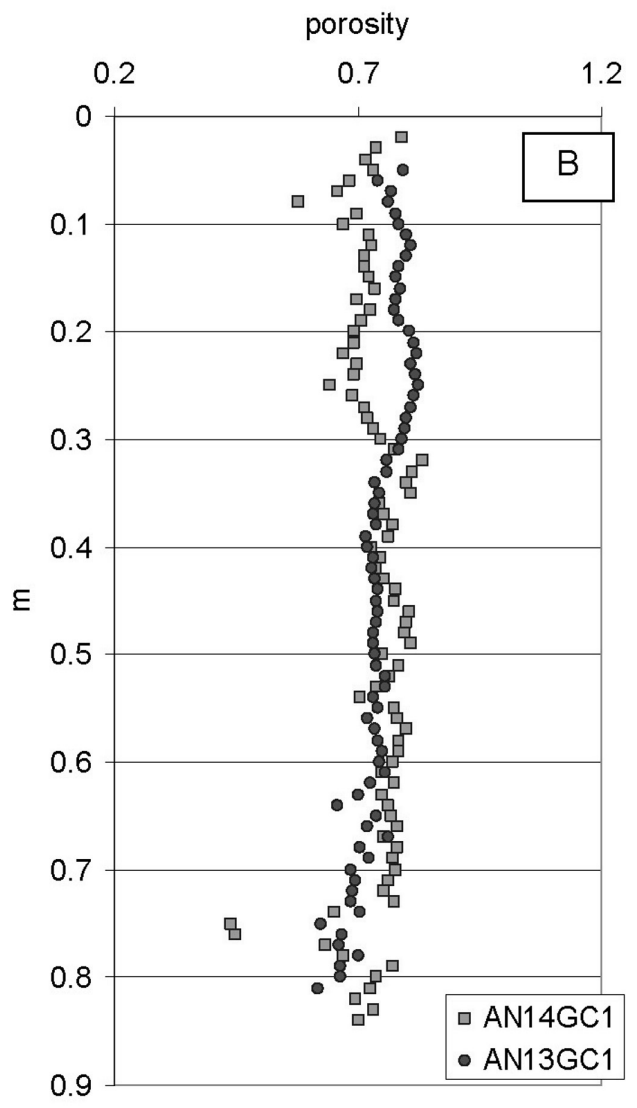

FIG. 10. - Core logs illustrating the vertical distribution of porosity (\%). 


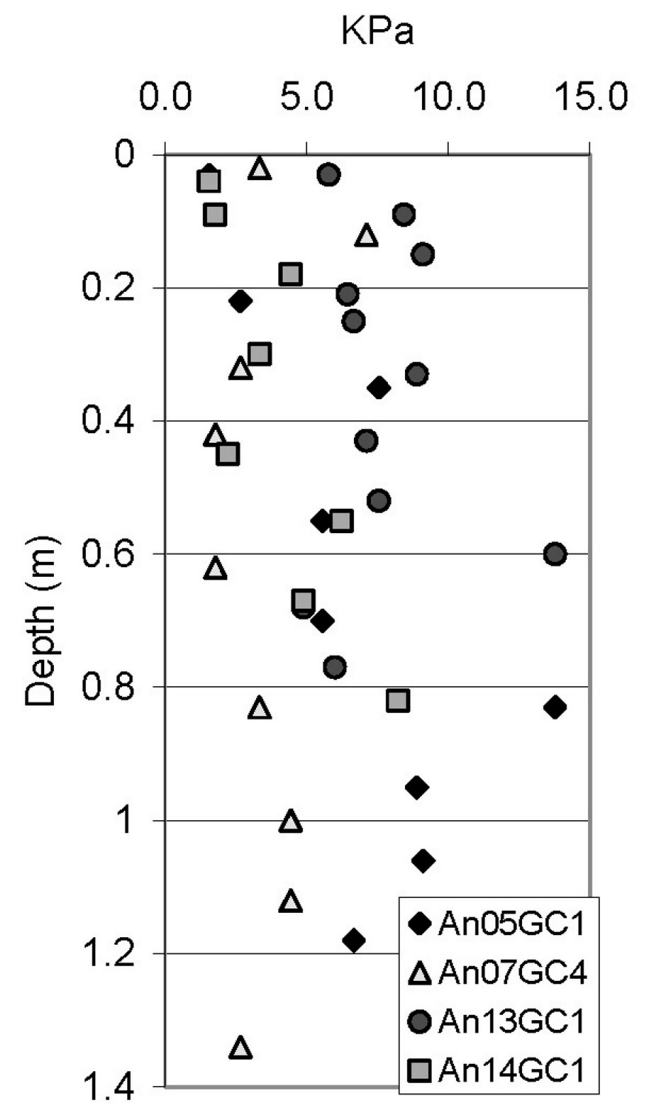

FIG. 11. - Downcore variation of shear strength $(\mathrm{kPa})$ for cores An05GC1, An07GC4, An13GC1 and An14GC1.

shows an average value of $7.7 \mathrm{kPa}$ and a maximum value of $14 \mathrm{kPa}$ at $0.6 \mathrm{mbsf}$.

In cores An05GC1, An07GC4 and An14GC1, with the same type of sediment along the core (mud breccia), the strength variations may be related to changes in the primary composition or to processes such as gas seepage which can break the internal structure of sediment. For core An13GC1, formed by a mud breccia overlaid with hemipelagic sediments, strength variations seem to correspond to specific sediment types or lithologic/compositional changes in the same type of sediment. For instance, low relative strength values $(6.4-6.7 \mathrm{kPa})$ correspond to the presence of the sapropel $\mathrm{S} 1$ between 15 to $33 \mathrm{cmbsf}$.

\section{DISCUSSION}

\section{Sedimentology: geological significance}

The geological interpretation of the sedimentology indicates that cores recovered from the crater of the Anaximander, Kula and Kazan mud volcanoes are formed by a mud breccia on the surface, which suggests recent activity or at least that they are not in a dormancy period. Likewise, the mud breccia succession probably results from individual eruption events due to the absence of phases of mud breccia oxidation and intercalations of hemipelagites. However, the sedimentology of core An13GC1, from the external flank of the Kula volcano, corresponds to an old extruded mudflow. After the deposition of the mud breccia this sediment was affected by an episode of oxidation due to its contact with the seawater, which was followed by a hemipelagic deposition. The $50 \mathrm{~cm}$ thick succession of hemipelagites suggests a prolonged period without mass flow deposition in the southwestern sector of the mud volcano flank.

Disseminated gas hydrate was recovered in the sediment cores, and this type of distribution implies low concentrations of gas hydrate, favouring its breakdown during the sampling and its disappearance in a short time when its stable P-T conditions change (Kvenvolden, 1993). The gas hydrate was observed in the mud breccia located in the active summits (or crater in the case of Amsterdam m.v.) of the mud volcanoes, but was absent from the mud breccia and hemipelagites located outside the active areas of the mud volcanoes (Lykousis et al., 2003). These observations suggest three possible explanations for the presence and formation of the gas hydrate: 1) its restricted location in the mud volcanoes, 2) the texture of the sediment, and 3) the mineralogy. Gas hydrate occurs at or near the surface of mud breccia sediments in the summit (or crater). High gas fluxes through the mud breccia due to the fluid dynamic processes (overpressured system) related to mud volcano formation and the presence of a relatively large volume of gas rising to the surface could favour the formation of gas hydrate (Casas et al., 2003). The texture is similar for the matrix of the mud breccia and hemipelagites, so in this particular case a textural control of the gas hydrate formation conditions for the sediment hosting it is not justified. Finally, recent studies on mineralogy suggest a close relationship between the type of minerals and the presence of gas hydrate. That areas with gas hydrate coincide with areas with high percentages of smectite is a recent discovery (Collet and Wendlandt, 2000); the smectite may act as a catalyst in the formation of gas hydrate and may also alter its stability. The clay mineralogy of the 
mud breccia from the Anaximander mud volcanoes is mostly characterized by the presence of smectite, with $89 \%$ in the Amsterdam and $85 \%$ in the Kazan mud volcanoes; illite and kailonite were also identified, although in lower percentages (Zitter, 2004). High percentages of smectite in the muddy-matrix of the mud breccia have also been observed in other mud volcanoes in the Mediterranean (JuradoRodríguez and Martínez-Ruiz, 1998; Zitter, 2004), and in other areas of the world, such as the Gulf of Cadiz (Martin, 2004) and Barbados (Lance et al., 1998). Pyrite (Fig. 7) is a mineral that can be indicative of the presence of gas in one area, and it has been found in mud breccias of other mud volcanoes containing gas and gas hydrate (Martín, 2004). Its proposed genesis is related to the bacterial activity of the consortium of sulphide-reducing bacteria and archaeae, which oxidize the methane and reduce the sulphate, favouring carbonate precipitation and sulphurs (Michaelis et al., 2002; Martín, 2004). Therefore, the presence of pyrite in the mud breccia recovered from Anaximander, Kazan and Kula could also be related to the observed gas hydrate and carbonate crusts.

\section{Physical properties}

One of the greatest advantages of the MSCL is that it allows us to obtain a high-resolution, continuous record of the physical properties of the sediment. The data ensure that the physical signals of all sediment types are measured. This is especially relevant when studying geological sections, like those cores studied here, in which the variability of sediment types is very low. MSCL measurements performed in the lab do not represent the undisturbed physical state of the in situ environment of gas hydrate formation, but it can be very useful to know the lithology and nature of the hosting sediment.

A low correlation was observed between some of the physical parameters measured with the MSCL sensors. In general, highs in density correspond to lows in magnetic susceptibility, but no statistical relationship confirmed this tendency. A low positive correlation $(\mathrm{R}=0.47)$ between density and $\mathrm{P}$-wave velocity was only observed in core An13GC1. These observations suggest that depth (i.e. increased consolidation), which correlates with density $(\mathrm{R}=0.72)$, is a significant factor affecting the physical properties of the sediment, especially the velocity.
The relationship between the physical properties and lithology showed correlations with density and MS. The density maximums for cores An05GC1, An07GC4 and An14GC1 generally coincide with the presence of large clasts or clusters of them. But the variability of density in cores An07GC4 and An14GC1 seems to be controlled respectively by the variability of silt $(\mathrm{R}=0.69)$ and sand $(\mathrm{R}=0.47)$, and by the variability of gravel $(\mathrm{R}=0.78)$, silt $(\mathrm{R}=-0.75)$ and clay $(\mathrm{R}=-0.78)$.

The density for core An13GC1 also shows some relationships with sedimentological parameters such as sand-density $(R=0.58)$, gravel-density $(R=0.65)$ and clay-density $(\mathrm{R}=-0.73)$. These correlations are influenced by the percentage variations of sand, gravel and clay with the core-depth and the increase in density downcore $(\mathrm{R}=0.72)$ as an effect of consolidation (by overburden).

With respect to MS, an acceptable correlation was only found with clay $(\mathrm{R}=0.49)$ in core An07GC4, and with silt $(\mathrm{R}=-0.6)$ in core An14GC1. Thus, MS seems to be controlled by the fine fraction. The MS in core An13GC1 also correlates with carbonate $(\mathrm{R}=0.73)$, silt $(\mathrm{R}=0.43)$, gravel $(\mathrm{R}=-0.55)$ and sand $(\mathrm{R}=-0.58)$ content. These correlations also reflect the different types of sediment, with the highest MS values corresponding to the hemipelagic layers, and the lowest to the hemipelagic organic-rich sediment and mud breccia (Fig. 5). In this case, the silt probably plays an important role since it is the most independent of these variables and may thus be important for explaining the absolute magnetic susceptibility values for this core.

Plots of velocity $v s$. porosity are particularly useful for distinguishing the state of consolidation of sediment vs. the extent of diagenesis. In general, increasing consolidation in soft sediments tends to increase velocity through a decrease in porosity; whereas, cementation produces an increase in velocity through increased rigidity of the sediment with little or no reduction in porosity (Dadey and Klaus, 1992). On a plot of velocity vs. porosity measurements of sediments from An014GC1 (Fig. 12A) and An013GC1 (Fig. 12B), we observed a general trend for velocity to increase as porosity decreases. A corresponding increase in $\mathrm{P}$-wave velocity is only observed for sediments with higher bulk densities $(\mathrm{R}=0.47)$ in core $\mathrm{An} 013 \mathrm{GC} 1$; in this case, there is a linear correspondence and a relatively good correlation for both measurements. These observations suggest that depth (i.e. increased consolidation) is a 
significant factor that affects the physical properties of the sediment, especially the velocity of core An013GC1.

\section{Index properties}

The index properties are all volumetric parameters calculated from the wet and dry weights and volumes of discrete samples. However, the relationships between some of the index properties are also controlled by lithology, especially the grain density which is the only parameter that depends mostly on the mineralogy of the samples. Grain size laboratory analysis showed that, despite the variability suggested by the differences observed visually between the types, almost all the sediment types recovered were of a similar size-range. Due to this low variability of sediment grain sizes, it is suggested that the greatest contribution to the variability observed in the physical properties would be made by either chemical/mineralogical variations or processes related to the consolidation of the sediment by overburden.

The average grain densities of the sediments described are $2.641 \mathrm{~g} / \mathrm{cm}^{3}$ for the hemipelagic sediment and $2.703 \mathrm{~g} / \mathrm{cm}^{3}$ for the matrix of mud breccias. These density values are close to the grain density of the most common constituents of the sediments, such as quartz $\left(2.64 \mathrm{~g} / \mathrm{cm}^{3}\right)$, calcite $(2.71$ $\mathrm{g} / \mathrm{cm}^{3}$ ) and clay minerals, which have highly variable grain densities, although the most common forms (smectite, kaolinite and montmorillonite) have average grain densities of 2.2 to $2.7 \mathrm{~g} / \mathrm{cm}^{3}$ (Johnson and Olhoeft, 1984).

There is a positive correlation between porosity and core-depth in cores An05GC1and An014GC1 (e.g. porosity increases with depth) and absence of correlation in core An07GC4. This can be explained by the presence of porous gas-release structures resulting from depressurization following the collection of samples. This effect is less significant in core An13GC1 since the coring site, which is located outside the crater of the mud volcano, has a different stratigraphy and lithology. In this case, the porosity and core-depth correlate negatively $(\mathrm{R}=-0.75)$.

Carbonate content is a parameter that normally has a large influence on the physical properties of the sediment. Sediments with silica and clay minerals in general have higher porosities than calcareous, so increases in carbonate tend to correlate with
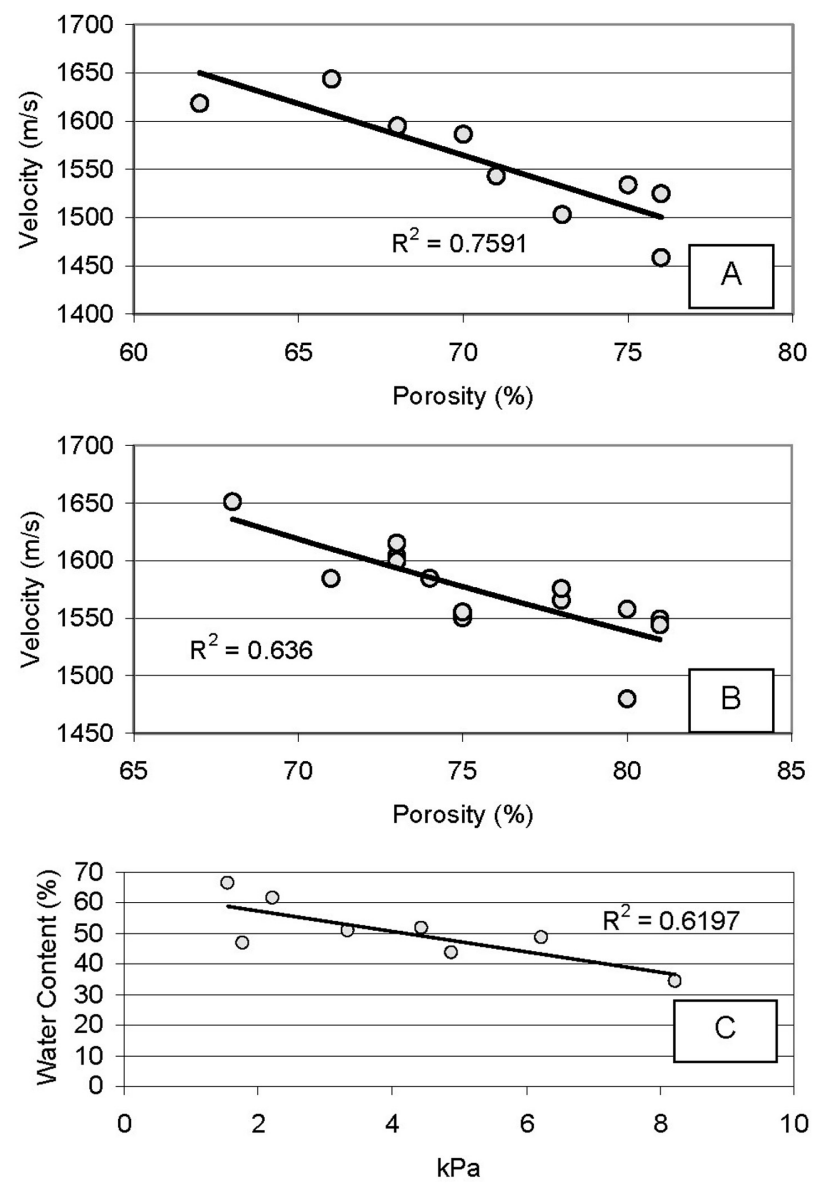

FIG. 12. - Graphic illustrating the relationship between porosity (\%) and P-wave velocity (m/s) in cores An014GC1 (A) and An013GC1 (B). And Diagram illustrating correlation between shear strength $(\mathrm{kPa})$ and water content (\%) for core An14gc1(C).

decreases in porosity (Nobes et al., 1991). Similar relationships are observed between bulk density and carbonate content (Hamilton et al., 1982). This relationship is not clear for the sediments recovered in the Anaximander area. A plot of carbonate vs. porosity for all analyzed samples (Fig. 13) shows a cloud of points with no observable trends. A plot of carbonate vs. grain density (Fig. 13) confirms that the two parameters are independent of each other. Grain density values are clustered in different groups for the mud breccia samples with a low carbonate content, and scattered for the hemipelagic samples with a high carbonate content. This could be due to the fact that the mud breccia is composed of a homogeneous group of minerals while the hemipelagic samples are composed of a greater variety of clay minerals and biogenic components.

Shear strength depends on the cohesion forces and on the friction between the coarser sediment particles. Progressive consolidation due to overburden results in the expulsion of interstitial water out 

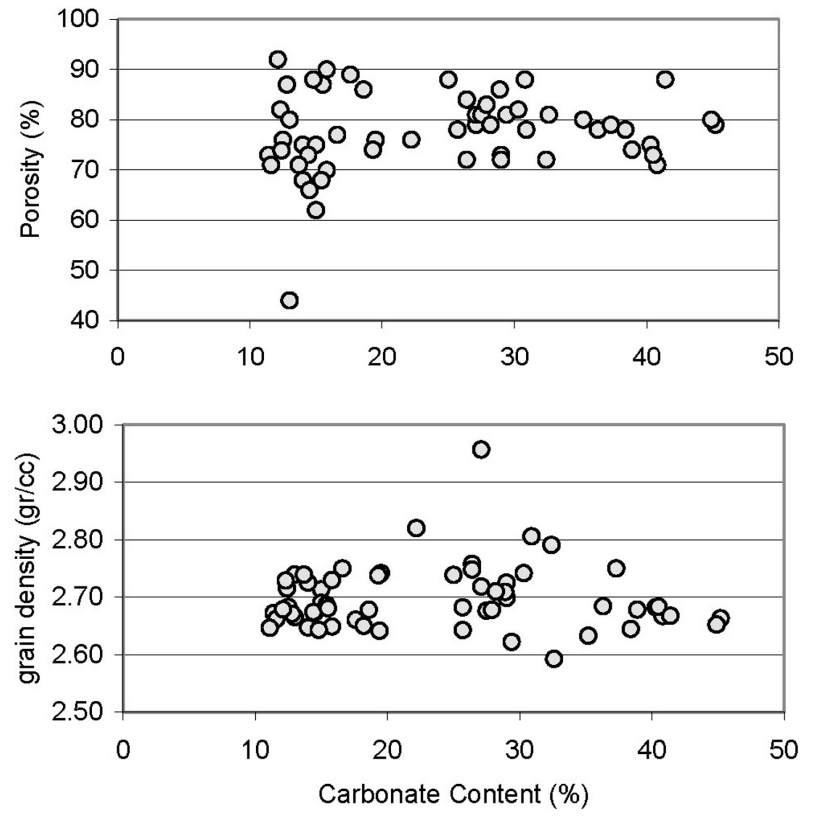

FIG. 13. - Graphic illustrating the relation between porosity $(\%)$ and carbonate content $(\%)$ and between grain density $\left(\mathrm{g} / \mathrm{cm}^{3}\right)$ and carbonate content $(\%)$ for all analysed samples.

of the sediment pores and the increase in the friction factor in the sediment strength. In general, in marine sediment shear strength values depend on water content. However, in our results shear strength and water content show a very low correlation with depth and, as stated above, the physical properties were not especially controlled by the consolidation in cores An05GC1, An07GC4 and An14GC1. Shear strength and water content also fail to show any acceptable correlation (when all the samples measured are taken into account). The literature suggests that this could be related to changes in the cohesive forces developed in the clay-rich sediments due to variations in the clay mineralogy (Schmincke et al., 1995). However, in our "gassy" cores an effect of the presence of porous gas-release structures resulting from depressurization following the collection of samples is also possible. In one particular case (An14GC1) a negative correlation is described (Fig. $12 \mathrm{C}$ ). The presence of gas hydrates in the mud breccia must affect its shear strength, and it is expected that this is greater than the measured values. Thus the depressurization may also be responsible for the relatively low strength values obtained.

Water content shows a low correlation with coredepth, but in all cases it shows a tendency to decrease downcore. The best result was found in core An13GC1 ( $\mathrm{R}=-0.61)$, where we also found "normal behaviour" of water content in comparison with the other variables, i.e. an increase in density $(\mathrm{R}=-0.82)$ and velocity $(\mathrm{R}=-0.56)$ is associated with a decrease in water content and a decrease in porosity $(\mathrm{R}=0.80)$ and the mean grain size in phi units $(\mathrm{R}=0.67)$. For the rest of the cores, these relationships are not very clear or are achieved only partially.

\section{CONCLUSIONS}

Two different types of sediments were defined, mud breccias and hemipelagic mud. The mud breccia is characterized by a high clay and silt content ranging between $67-56 \%$ and $19-30 \%$, with a sand and gravel content of about $14 \%$. Hemipelagic mud is characterized by a high clay and silt content and a sand content of only $3 \%$. The stratigraphy of cores An05GC1, An07GC4 and An14GC1 comprises mud breccias, whereas the core An013GC1 is defined by mud breccias that toward the top change to hemipelagic mud (an organic-rich bed is identified within it); the contact between the two types of sediment is sharp.

Some differences between cores were identified from the statistical correlation of the different parameters studied. For cores An05GC1, An07GC4 and An14GC1 the physical properties are mainly controlled by lithology. This is supported by the correlations found between density and sand or silt in core An07gc4 and between density and gravel or silt in core An14GC1. The MS of these cores seems to be controlled by the fine fraction. The physical properties of core An013GC1 are mostly related to consolidation (compactation by overburden), but at a detailed scale they show variations related to variations in the defined texture (hemipelagic mud vs. mud breccia). This is supported by the relationships found between density and core-depth (which is the most significant) and the correlation between density and $\mathrm{P}$-wave or porosity and $\mathrm{P}$-wave. The influence of variation in grain-size is observed due to the relationships between density and clay or gravel. In this case, the magnetic susceptibility seems to be controlled by the coarser fraction (gravel, silt and sand).

The statistical correlation indicates that carbonate content does not correlate with changes in porosity and grain density in the four cores. This suggests that carbonate content does not show any evident effect on the physical properties of the sediments.

Water content shows a low correlation with coredepth, but in all cases it shows a tendency to decrease 
downcore. We found "normal behaviour" of water content in comparison with the other variables only in core An13GC1, i.e. an increase in density and velocity is associated with a decrease in water content and a decrease in the porosity and mean grain size. The "normal behaviour" of this core is possible because it is from a non-active site, with fluids passing through it. For the rest of the cores, these relationships are achieved only partially.

Shear strength mainly has a low or null correlation with core-depth. A negative correlation was only observed between shear strength and water content in core An14Gc1. For the rest of the cores, the shear strength could reflect the effect of the presence of porous gas-release structures resulting from depressurization after collecting samples containing gas hydrate.

The stratigraphy and the above-mentioned correlations suggest that for the sediment cores located in the active part of the mud volcanoes (An05GC1, An07GC4 and An14GC1), the physical properties are controlled by lithology and mud volcanic processes rather than by degree of compaction. This could suggest recent fluid circulation, and therefore the possibility of current mud volcanic activity in the studied volcanoes. In contrast, the core located in the inactive part of the Kula mud volcano (An13GC1) displayed physical properties mostly related to consolidation effects, (even though it is composed partially by mud breccias) and to the type of sediment at a detailed scale, as occurs typically in deep sea fine-grained sediments. This suggests that mud volcanic processes have a restricted influence, i.e. fluid circulation out of the summit or crater of the mud volcanoes.

The Multi Sensor Core Logger measurements do not represent the undisturbed or in-situ physical properties of sediment containing gas hydrates. Moreover, it is difficult to establish the degree of disturbance after the gas hydrate dissociation. This is enough to justify the need for advanced tools, such as APCA (Advanced Piston Core), to get pressurized sediment cores (Amann et al., 2000). These tools improve the process of recovering sediment hosting free gas and gas hydrates. In the studied cores, as it has been noted, the release of gas influenced the general structure of sediment, but it has not been distorted or destroyed. This is why the relationships shown are still convincing and describe, at least relatively, the behaviour in the different environments sampled. MSCL measurements are also very useful for learning about the lithology and nature of the sediment hosting gas hydrates.

\section{ACKNOWLEDGEMENTS}

This work was founded by the European Commission ANAXIMANDER project (EVK32001-00123), and by the "Ministerio de Ciencia y Tecnología" MARCONI (REN2000-0336-C03) project and ERGAP (VEM2003-20093-C03) project. The support of these people and institutions is gratefully acknowledged. David Casas thanks the Generalitat de Catalunya for the PhD grant (1999FI 00002CSIC PG).

\section{REFERENCES}

Amann, H., J. Baraza, C. Marx, C. Perissoratis, J. Roberts, A. Skinner, P. Valdy and H. Zuidberg. - 2000. Hyace, an autoclave coring equipment for systematic offshore sampling, measurement and ground truthing. Eurocean 2000, pp. 670-673.

Aloïsi, G.I., I. Bouloubassi, K. Heijs, R.D. Pancost, J.S. Sinninghe and J.C. Gottschal. - 2002. Methane-consuming microorganisms and the formation of carbonate crusts at seeps. Earth Planet Sci. Lett., 203: 195 -203.

Casas, D., G. Ercilla and J. Baraza. - 2003. Acoustic evidences of gas in the continental slope sediments of Gulf of Cadiz (E Atlantic). Geo-Mar Lett., 23: 300-310.

Casas, D., H. Lee, G. Ercilla, R. Kayen, F. Estrada, B. Alonso, J. Baraza and F. Chiocci. - 2004. Physical and geotechnical properties and assessment of sediment stability on the continental slope and basin of the Bransfield Basin (Antarctica Peninsula). Mar. Georesources Geotechnol., 22(4): 253-278.

Charlou, J.L., J.P. Donval, T. Zitter, N. Roy, P. Jean-Baptiste, J.P. Foucher, J. Woodside and the MEDINAUT Scientific Party. 2003. Evidence of methane venting and geochemistry of brines on mud volcanoes of the eastern Mediterranean Sea. Deep-Sea Res., Part I, 50: 941-958.

Collet, T.S. and R.F. Wendlandt. - 2000. Formation evaluation of gas hydrate-bearing marine sediments on the Blake Ridge with downhole geochemical log measurements. Procc. ODP, Results, 164: 199-215.

Dadey, K.A. and A. Klays. - 1992. Physical properties of volcanoclastic sediments in the Izu-Bonin area. In: B. Taylor, K. Fujioka, et al. (eds.), Proc. ODP, Sci. Res., 126, pp. 543-550 College Station, TX (Ocean Drilling Program).

Fleming, N. - 1972. Eustatic and tectonic factors in the relative vertical displacement of the Aegean coast. In: D. Stanley (ed.), The Mediterranean Sea, pp. 189-201. Dowden, Hutchinson \& Ross, Stroudsberg.

Fulthorpe, C.S., S.O. Schlanger and R.D. Jarrard. - 1989. In situ acoustic properties of pelagic carbonate sediments on the Ontong Java Plateau. J. Geophys. Res., 94: 4024-4032.

Giró, S. and A. Maldonado. - 1987. Análisis granulométrico por métodos automáticos. Tubo de sedimentación y Sedigraph. Acta Geol. Hispánica, 20(1): 95-102.

Hamilton, E.L. - 1970. Sound velocity and related properties of marine sediments. J. Geophys. Res., 75: 4423-4446.

Hamilton, E.L. and R.T. Bachman. - 1982. Sound velocity and related properties of marine sediments. J. Acoust. Soc. Am., 72: 1891-1904.

Hamilton, E.L., R.T. Backman, W.H. Berger, T.C. Johnson and L.A. Mayer. - 1982. Acoustic and related properties of calcareous deep-sea sediments. J. Sediment. Petrol., 52: 733-753.

Johson, G.R. and G.R. Olhoeft. - 1984. Density of rocks and min- 
erals. In: R.S. Carmichael (ed.), CRC Handbook of Physical Properties of Rocks (Vol. 3): Boca Raton, FL (CRC Press, Ins.), $1-38$.

Jurado-Rodríguez, M.J. and F. Martínez-Ruiz. - 1998. Some clues about the Napoli and Milano mud volcanoes from an integrated log-core approach. Proc. ODP, Sci. Res, 160: 607-623.

Kim, D.C., J.Y. Sung, S.C. Park, G.H. Lee, J.H. Choi, G.Y. Kim, Y.K. Seo and J.C. Kim. - 2001. Physical and acoustic properties of shelf sediments, the South Sea of Korea. Mar. Geol., 179: $39-50$.

Kvenvolden, K.A. - 1993. Gas hydrates. Global perceptive and global change: Rev. Geophys., 31: 173-187.

Lance, S., P. Henry, X. Le Pichon, S. Lallement, H. Chamley, F. Rostek, J.C. Faugeres, E. Gonthier and K. Olu. - 1998 Submersible study of mud volcanoes seaward of the Barbados accretionary wedge: sedimentology, structure and rheology. Mar. Geol., 145: 255-292.

Lee, H. and J. Baraza. - 1999. Geotechnical characteristics and slope stability in the Gulf of Cadiz. Mar. Geol., 155: 173-190.

Lykousis, V., J. Woodside, G. de Lange, S. Alexandri, D. Sakellariou, P. Nomikou, Chr. Ioakim, A. Daehlman, D. Casas, G. Rousakis, D. Ballas, K. Kormas, S. Kioroglou and C. Perissoratis. - 2003. Mud volcanoes and related gas hydrates in Anaximander Mountains (Eastern Mediterranean). New discoveries from the 01/May03 cruise of R/V Aegaeo (Anaximander Project). Ocean Margin Research Conference (EC and UNESCO). Paris (France) 15-17 September.

Lykousis, V., S. Alexandri, J. Woodside, P. Nomikou, Chr. Ioakim, D. Sakellariou, G. de Lange, A. Daehlman, D. Casas, G. Rousakis, D. Ballas and C. Perissoratis. - 2004. New evidence of extensive active mud volcanism in the Anaximander Mountains (Eastern Mediterranean): The ATHINA mud volcano. Environ. Geol., 46(8): 1030-1037.

Lykousis, V., S. Alexandri, J. Woodside, G. de Lange, A. Daehlman, C. Perissoratis, Chr. Ioakim, D. Sakellariou, P. Nomikou, D. Casas, K. Kormas, G. Rousakis, D. Ballas and G. Ercilla. - 2006. Mud volcanoes and gas hydrates in Anaximander Mountains (Eastern Mediterranean): Mar. Pet. Geol. Submitted.

Martín, C. - 2004. Caracterización mineralógica de estructuras ligadas a escapes de metano en el Golfo de Cádiz. Tesis de licenciatura. Univ. Cádiz-Instituto Español de Oceanografía.

McClusky, S., S. Balassanian, A. Barka, C. Demir, S. Ergintav, I. Georgiev, O. Gurkan, M. Hamburger, K. Hurst, H. Kahle, K. Kastens, G. Kekelidze, R. King, V. Kotzev, O. Lenk, S. Mahmoud, A. Mishin, M. Nadariya, A. Ouzounis, D Paradissis, Y. Peter, M. Prilepin, R. Reilinger, I. Sanli, H. Seeger, A. Tealeb, M.N. Toksoz and G. Veis. -2002 . GPS constraints on plate kinematics and dynamics in the eastern Mediterranean and Caucasus. J. Geophys. Res., 105: 5695-5719

Michaelis W., R. Seifert, K. Nauhaus, T. Treude, V. Thiel, M. Blumrnberg, K. Knittel, A. Gieseke, K. Peternecht, T. Pape, A Boetius, R. Amann, BB. Jorgensen F. Widdel J. Peckmann, Pimenov NV and MB. Gulin. - 2002. Microbial reefs in the Black Sea fuelled by anaerobic oxidation of methane. Science, 297: 1013-1015.

Mienert, J. - 1984. The importance of carbonate content in the acoustic stratigraphy of Panama Basin. Mar. Geol., 54: 237-247.

Mienert, J., W.B. Curry and M. Sarnthein. - 1988 Sonostratigraphic records from equatorial Atlantic deep-sea carbonates: paleoceanographic and climatic conditions. Mar. Geol., 83: 9-20.

Milkov, A.V. - 2000. Worldwide distribution of submarine mud volcanoes and associated gas hydrates. Mar. Geol., 167: 29-42.

Nelson, C.H., J. Baraza, A. Maldonado, J. Rodero, C. Escutia and J.H. Barber Jr. - 1999. Influence of the Atlantic inflow and Mediterranean outflow on late Quaternary sedimentary facies of the Gulf of Cadiz continental margin. Mar. Geol., 155: 99-129.

Nobes, D.C., H. Villinger, E.E. Davis and L.K. Law. - 1986. Estimation of marine sediments bulk physical properties at depth from seafloor geophysical measurements. J. Geophys. Res., 91: 14033-14043.

Nobes, D.C., J. Mienert and G.J. Dirksen. - 1991. Lithologic control of physical-property interrelations. In: P.F. Ciesielski, Y. Kristoffersen, et al. (eds.), Proc. ODP, Int. Repts., 114: College Stations, TX (Ocean Drilling Program), 657-669.

Nobes, D.C., M.G. Langseth, S. Kuramoto, P. Holler and N. Hirata.
- 1992. Comparison and correlation of physical-property results from Japan Sea Basin and Rise Sites, legs 127 and 128. In: K. Tamaki, K. Suyehiro, J. Allan, M. McWilliams, et al., (eds.), Proc. ODP, Int. Repts., 127/128, Pt. 2: College Station, TX (Ocean Drilling Program), 1275-1296.

Olu-Le, R.K., M. Sibuet, A. Fiala-Medioni, S. Gofas, C. Salas, J.P. Foucher and J. Woodside. - 2004. Cold seep communities in the deep eastern Mediterranean Sea: composition and spatial distribution on mud volcanoes Deep-Sea Res. Part I: Oceanogr. Res. Papers, 51: 1915-1936.

Orsi, T.H. and D.A. Dun. - 1991. Correlations between sound velocity and related properties of glacio-marine sediments: Barents Sea. Geo-Mar Lett., 11: 79-83.

Pellenberg, R.E. and M.D. Max. - 2000. Introduction, Physical Properties, and Natural Occurrences of Hydrate. In: D. Max (ed.), Natural Gas Hydrate: in Oceanic and Permagrost Environments. Kluwer Academic Publishers, Netherlands, 5: 1-8.

Rijk, S., A. Hayes and E.J. Rohling. - 1999. Eastern Mediterranean sapropel S1 interruption: an expression of the onset of climatic deterioration around 7 ka BP. Mar. Geol., 153: 337-343.

Robinson, S.G. - 1990. Application for whole-core magnetic susceptibility measurements of deep-sea sediments: Leg 115 results. In: R.A. Duncan, J. Backman, L.C. Peterson, et al. (eds.), Proc. ODP, Int. Repts., 115: College Station, TX (Ocean Drilling Program), 737-771.

Sager, W.W. and S.A. Hall. - 1990. Magnetic properties of black mud turbidites from ODP Leg 116, distal Bengal Fan, Indian Ocean. In: J.R. Cochran et al. (eds.), Proc. ODP, Int. Repts., 116: College Station, TX (Ocean Drilling Program), 317-336.

Salas, C. and J.M. Woodside. - 2002. Lucinoma kazani n. sp. (Mollusca: Bivalvia): evidence of a living benthic community associated with a cold seep in Eastern Mediterranean Sea. Deep-Sea Res., 49: 991-1005.

Stein, R. - 1985. Rapid grain size analyses of clay and silt fraction by Sedigraph 5000D: comparison with Coulter Counter and Atterberg methods. J. Sediment. Petrol., 55: 590-615.

Ten Veen, J.H., J. Woodside, T.A.C. Zitter, J. Dumont, J. Mascle and A. Volkonskaia. - 2004. Neotectonic evolution of the Anaximander Mountains at the junction of the Hellenic and Cyprus arcs. Tectonophysics. 391: 1-4, 35-65.

Vatan, A. - 1967. Manuel de Sédimentologie. Technip., Paris.

Weber, M., F. Niessen, G. Kuhn and M. Wiedicke. - 1997. Calibration and application of marine sedimentary physical properties using a multi-sensor core logger. Mar. Geol., 136: $151-172$

Werne J.P., R.R. Haese, T. Zitter, G. Aloisi, L. Bouloubassi, S. Heijs, A. Fiala-Medioni, R.D. Pancost, J.S.S. Damste, G. de Lange, L.J. Forney, J.C. Gottschal, J.P. Foucher, J. Mascle and J. Woodside. - 2004. Life at cold seeps: a synthesis of biogeochemical and ecological data from Kazan mud volcano, eastern Mediterranean Sea. Chem. Geol., 205(3-4): 367-390.

Woodside, J.M., M.K. Ivanov and A.F. Limonov. - 1997. Neotectonics and fluid flow through the seafloor sediments in the Eastern Mediterranean and Black Seas. Part I: Eastern Mediterranean Sea. IOC Technical Series, 48: 1-128.

Woodside, J.M., M.K. Ivanov, A.F. Limonov and Shipboard Scientists of the Anaxiprobre expeditions. - 1998. Shallow gas and gas hydrates in the Anaximander Mountains region, eastern Mediterranean Sea. In: J.-P. Henriet and J. Mienert (eds.), Gas Hydrates: Relevance to World Margin Stability and Climate Change. Geological Society, London, Special Publications, 137: 177-193.

Zitter, T.A., J.M. Woodside and J. Mascle. - 2003. The Anaximander Mountains: a clue to the tectonics of southwest Anatolia. Geol. J., 38: 375-394.

Zitter, T.A. - 2004. Clay mineral provenance in mud breccias of Eastern Mediterranean mud volcanoes. Chapter 4. Ph.D. thesis, Free Univ. Amsterdam.

Zitter, T.A., C. Huguen and J.M. Woodside. - 2005. Geology of mud volcanoes in the Eastern Mediterranean from combined sidescan and submersible surveys. Deep Sea Res. Part I. Oceanogr. Res. Papers, 52(3): 457-475.

Received September 1, 2005. Accepted May 4, 2006.

Scient. ed.: A. Palanques.

Published online November 17, 2006. 
